\title{
PENGARUH PENAMBAHAN SERAT TANDAN SAWIT TERHADAP KUAT TEKAN DAN KUAT LENTUR BETON
}

\author{
Khairul Amna $^{1)}$, Wesli $^{2)}$, Hamzani ${ }^{3)}$ \\ Jurusan Teknik Sipil, Fakultas Teknik, Universitas Malikussaleh \\ email: ${ }^{1)}$ khairul.amna09@gmail.com ${ }^{2)}$ ir_wesli@yahoo.co.id
}

\begin{abstract}
Abstrak
Beton merupakan pilihan utama untuk membuat kontruksi saat ini. Kelemahan beton sebagai bahan konstruksi adalah kuat lentur yang rendah dan sifatnya yang getas. Perbaikan kelemahan sifat beton tersebut bisa dengan menambahkan serat (fiber) dalam adukan beton. Pada penelitian ini serat yang digunakan adalah serat alam, yaitu serat tandan kosong kelapa sawit. Serat dibilas dengan larutan $10 \%$ $\mathrm{NaOH}$ selama 12 jam, dikeringkan dan dipotong-potong sepanjang $4 \mathrm{~cm}$. Variasi persentase serat terhadap berat volume semen di dalam campuran adalah $5 \%$, $10 \%$, dan $15 \%$. Hasil penelitian menunjukkan untuk setiap veriasi persentase serat tidak dapat meningkatkan kuat tekan beton dan penurunan terbesar pada variasi serat $10 \%$, yaitu sebesar $20,15 \%$ dari kuat tekan normal. Sedangkan kuat lentur, peningkatan maksimum pada variasi serat $10 \%$, yaitu sebesar $19,77 \%$ dari kuat lentur normal. Berdasarkan persamaan regresi linier komposisi optimum serat yang dapat meningkatkan kuat lentur dengan kuat tekan masih dalam batasan kuat tekan rencana, yaitu pada variasi $12 \%$ serat dengan kuat lentur 3,99 Mpa (meningkat 14,33\% dari kuat normal) dengan kuat tekan 20 Mpa. Sehingga pemanfaatan serat tandan sawit sebagai serat beton bisa dikembangkan.

Kata kunci: Serat Tandan Kosong Kelapa Sawit, Kuat Lentur, Kuat Tekan, Regresi Linier.
\end{abstract}

\section{Pendahuluan}

Beton merupakan suatu benda padat yang terbentuk dengan cara mencampur agregat kasar, agregat halus, dan bahan tambah (admixture atau additivie) dengan suatu pasta yang terbuat dari semen dan air. Kekuatan konstruksi beton sangat berpengeruh terhadap kualitas semen, jenis material yang digunakan, ikatan/adesi antar material, pemadatan dan perawatannya. Beton juga memiliki banyak kelebihan dibandingkan bahan konstruksi lainnya, antara lain beton dapat dengan mudah dibentuk sesuai dengan kebutuhan konstruksi, tahan temperature tinggi, mampu memikul bedan tekan, dan biaya pemeliharaan yang kecil. Terlepas dari itu semua, beton juga memiliki kekurangan tentunya.

Kelemahan beton sebagai bahan konstruksi adalah kuat lentur yang rendah dan sifatnya yang getas, karena itu beton membutuhkan solusi lain utuk menahan kuat lentur yang terjadi. Pada beberapa negara maju seperti Amerika dan Inggris, telah dikembangkan konsep perbaikan kelemahan sifat beton tersebut dengan menambahkan serat (fiber) pada adukan beton. Konsep dasarnya adalah untuk menulangi beton secara alami dengan serat yang disebarkan acak ke dalam adukan beton, sehingga dapat mencegah terjadinya retakan yang terlalu dini baik akibat beban maupun akibat panas hidrasi.

Banyak sekali serat yang dapat digunakan untuk memperbaiki sifat - sifat beton. Jenis serat tersebut antara lain serat baja, serat plastik, serat karbon, serat 
alam, dan serat fiberglass. Pada penelitian ini serat yang digunakan adalah serat alam, yaitu serat tandan kosong kelapa sawit yang merupakan limbah dari pabrik minyak sawit. Mengingat Indonesia merupakan salah satu negara terbesar penghasil kelapa sawit di dunia dengan luas areal 3,76 juta $\mathrm{Ha}$ atau 31,4 \% dari luas total kebun kelapa sawit dunia dan menghasilkan serat tandan kosong kelapa sawit mencapai 37 juta ton/tahun yang secara keseluruhan belum dimanfaatkan secara maksimal.

Adapun tujuan pada penelitian ini adalah untuk mengetahui persentase berat optimum campuran serat tandan kosong kelapa sawit yang menghasilkan kuat tekan dan lentur beton maksimum dengan persentase campuran 5\%,10\%, dan $15 \%$, dan seberapa besar pengaruh penambahan serat tandan kosong kelapa sawit pada setiap variasi serat yang ditambahkan dalam campuran beton terhadap kuat tekan dan kuat lentur beton, dengan kuat tekan beton rencana f'c sebesar $20 \mathrm{Mpa}$ dan FAS rencana sebesar 0,50.

\section{Tinjauan Kepustakaan}

\subsection{Pengertian Beton}

Menurut Mulyono (2004), beton merupakan fungsi dari bahan penyusunnya yang terdiri dari bahan semen hidrolik (portland cement), agregat kasar, agregat halus, air dan bahan tambah (admixture atau additivie). Kekuatan konstruksi beton sangat berpengeruh terhadap jenis material yang digunakan. Beton memiliki kelebihan dan kekurangannya masing-masing, yaitu:

a. Kelebihan

- Dapat dengan mudah dibentuk sesuai dengan keperluan konstruksi.

- Mampu memikil beban yang berat.

- Tahan terhadap temperature yang tinggi dan biayai pemilaharaan yang kecil.

b. Kekurangan

- Bentuk yang sudah dibentuk sulit diubah.

- Pelaksanaan pekerjaannya membutuhkan ketelitian yang tinggi dan berat.

- Daya pantul surve yang besar.

\subsection{Jenis-jenis Beton}

Menurut Mulyono (2004), Beton dapat dibedakan menjadi tiga berdasarkan beratnya yaitu beton berat, beton sedang dan beton ringan. Beton dapat pula dibedakan berdasarkan material penyusunnya dan kegunaan strukturnya. Beton jenis lain pada prinsipnya sama dengan beton normal, yang membedakan adalah material tambahan yang digunakan. Berikut jenis-jenis beton yang digunakan dalam beberapa konstruksi:

\section{a. Beton ringan}

Berdasarkan Mulyono (2004), agregat yang digunakan untuk memproduksi beton ringan merupakan agregat ringan juga. Agregat yang digunakan umumnya merupakan hasil pembakaran shale, lempung, slates, residu slag, residu batu-bara, dan banyak lagi dari hasil pembakaran vulkanik. Berat jenis agregat ringan sekira $1900 \mathrm{~kg} / \mathrm{m}^{3}$ atau berdasarkan kepentingan penggunaan strukturnya berkisar antara $1440-1850 \mathrm{~kg} / \mathrm{m}^{3}$, dengan kekuatan tekan umur 28 hari lebih besar dari 17,2 Mpa. 


\section{b. Beton normal}

Berdasarkan Anonim 1, beton normal merupakan beton yang mempunyai berat satuan $2200 \mathrm{Kg} / \mathrm{m}^{3}$ sampai $2400 \mathrm{Kg} / \mathrm{m}^{3}$ dan dibuat mengunakan agregat alam yang dipecah atau tanpa pecah.

\section{c. Beton berat}

Beton berat adalah beton yang dihasilkan dari agregat yang mempunyai berat isi lebih besar dari beton normal atau lebih dari $2400 \mathrm{~kg} / \mathrm{m}^{3}$. Beton yang mempunyai berat yang tinggi ini biasanya digunakan untuk kepentingan tertentu seperti menahan radiasi, menahan benturan dan lainnya (Mulyono, 2004).

\section{d. Beton serat (fibre concrete)}

Merupakan campuran beton ditambah serat, umunya berupan benang-benang dengan ukuran 5-500 $\mu \mathrm{m}$, dengan panjang sekitar $25 \mathrm{~mm}$. Bahan serat dapat berupa serat asbestos, selat plastic (poly-propylene), serat alam, atau potongan kawat baja. Kelemahannya sulit dikerjakan, namun lebih banyak kelebihannya antara lain kemungkinan terjadi segregasi kecil, daktail, dan tahan benturan (Mulyono, 2004)

\subsection{Material Penyusun Beton}

Bahan campuran beton biasanya terdiri dari semen, agregat halus, agregat kasar, air dan bahan tambah.

\section{a. Semen}

Semen adalah suatu jenis bahan yang memiliki sifat adhesive (adhesive) dan kohesife (cohesive) yang memungkinkan melekatnya fragmen-fragmen mineral menjadi suatu massa padat. Meskipun definisi ini dapat diterapkan untuk banyak jenis bahan, semen yang dimaksudkan untuk konstruksi beton bertulang adalah bahan yang jadi dan mengeras dengan adanya air yang dinamakan semen hidraulis (hydraulic cements) (Chu-Kia Wang, 1993).

b. Agregat halus

Agregat halus merupakan pengisi yang berupa pasir yang mempunyai BJ 1400 $\mathrm{kg} / \mathrm{m}$. Agregat halus yang baik harus bebas bahan organik, lempung, partikel yang lebih kecil, atau bahan-bahan lain yang dapat merusak campuran. Variasi ukuran dalam suatu campuran harus mempunyai gradasi yang baik. Berdasarkan Anonim 1, agregat halus adalah pasir alam sebagai hasil desintegrasi secara alami dari batu atau pasir yang dihasilkan oleh industri pemecah batu dan mempunyai ukuran butir terbesar 5,0 $\mathrm{mm}$.

Tabel 1 Gradasi Agregat Halus

\begin{tabular}{|c|c|c|}
\hline $\begin{array}{c}\text { Diameter Saringan } \\
(\mathrm{mm})\end{array}$ & Persen Lolos $(\%)$ & Gradasi Ideal $(\%)$ \\
\hline 9,50 & 100 & 100 \\
\hline 4,75 & $95-100$ & 97,5 \\
\hline 2,36 & $80-100$ & 90 \\
\hline 1,18 & $50-85$ & 67,5 \\
\hline 0,600 & $25-60$ & 42,5 \\
\hline 0,300 & $5-30$ & 17,5 \\
\hline 0,150 & $0-10$ & 5 \\
\hline
\end{tabular}

Sumber: Anonim 8 (2002) 


\section{c. Agregat kasar}

Agregat kasar adalah batuan yang ukuran butirnya lebih besar dari $4.80 \mathrm{~mm}$ $(4.75 \mathrm{~mm})$ dan agregat halus adalah batuan yang lebih kecil dari $4.80 \mathrm{~mm}$ $(4.75 \mathrm{~mm})$. Agregat dengan ukuran lebih besar dari $4.80 \mathrm{~mm}$ dibagi lagi menjadi dua : yang berdiameter antara 4.80 - $40 \mathrm{~mm}$ disebut kerikil beton dan yang lebih dari $40 \mathrm{~mm}$ disebut kerikil kasar (Mulyono, 2004).

Menurut Anonim 1 (2000), agregat kasar adalah kerikil sebagai hasil desintegrasi alami dari batu atau berupa batu pecah yang diperoleh dari industri pemecah batu dan mempunyai ukuran butir antara $5 \mathrm{~mm}-40 \mathrm{~mm}$.

Tabel 2 Persyaratan batas-batas susunan besar butir agregat kasar (kerikil atau koral)

\begin{tabular}{|c|c|l|l|}
\hline \multirow{2}{*}{ Ukuran Mata Ayakan (mm) } & \multicolumn{3}{|c|}{ Persentase berat bagian yang lewat ayakan } \\
\cline { 2 - 4 } & \multicolumn{3}{|c|}{ Ukuran nominal agregat (mm) } \\
\hline & $38-4,76$ & $19,0-4,76$ & $9,6-4,76$ \\
\hline 38,1 & $95-100$ & 100 & - \\
\hline 19,0 & $37-70$ & $95-100$ & 100 \\
\hline 9,52 & $10-40$ & $30-60$ & $50-85$ \\
\hline 4,76 & $0-5$ & $0-10$ & $0-10$ \\
\hline
\end{tabular}

Sumber: Anonim 1 (2000)

d. Air

Menurut Mulyono (2004), air diperlukan pada pembuatan beton untuk memicu proses kimiawi semen, membasahi agregat dan memberikan kemudahan dalam pekerjaan beton Air yang digunakan pada campuran beton ialah yang dapat diminum. Air yang dimaksud di sini adalah air yang tidak mengandung senyawa-senyawa berbahaya, yang tercemar garam, minyak, lumpur dan bahan-bahan kimia lainnya, bila digunakan dalam campuran beton akan menurunkan kualitas beton, bahkan dapat mengubah sifat-sifat beton yang dihasilkan. Sebelum digunakan air terlebih dahulu diperiksa di Laboratorium baru kemudian bisa digunakan.

e. Bahan tambah

Berdasarkan Anonim 1 (2000), bahan tambah adalah bahan yang ditambahkan pada campuran bahan pembuatan beton untuk tujuan tertentu. Admixture adalah bahan-bahan yang ditambahkan ke dalam campuran beton pada saat atau selama pencampuran berlangsung. Fungsi dari bahan ini adalah untuk mengubah sifat-sifat dari beton agar menjadi lebih cocok untuk pekerjaan tertentu, atau untuk menghemat biaya (Mulyono, 2004).

- Serat tanda sawit

Menurut Subyakto (2012), Indonesia mempunyai kekayaan sumber daya alam serat non kayu yang melimpah dan yang belum dimanfaatkan secara maksimal. Serat non kayu merupakan serat yang berasal dari tanamantanaman serat alam (seperti sisal, rami, kenaf, nenas), bambu, serta limbah pertanian dan perkebunan. Serat tandan sawit juga merupakan serat not kayu yang tersedia cukup banyak di Indonesia. Dari data tahun 2009, Indonesia menghasilkan serat pelepah sawit 80 juta ton, tandan kosong sawit 37 juta ton, batang sawit 16,4 juta ton (Gurning, 2013). 


\subsection{Pengujian Benda Uji}

Pengujian benda uji dapat dilakukan terhadap kuat tekan beton dan kuat lentur beton

\section{a. Pengujian Kuat Tekan Beton}

Menurut Mulyono (2004), bahwa kuat tekan beton adalah kemampuan beton untuk menerima gaya tekan persatuan luas. Walaupun dalam beton terdapat tegangan tarik yang kecil, diasumsikan bahwa semua tegangan tekan didukung oleh beton tersebut.

Rumus yang digunakan untuk perhitungan kuat tekan beton adalah sebagai berikut:

$$
f=\frac{P}{A}
$$

di mana:

$$
\begin{aligned}
& \mathrm{f}=\text { Kuat tekan }\left(\mathrm{kg} / \mathrm{cm}^{2}\right) \\
& \mathrm{A}=\text { Luas penampang benda uji }\left(\mathrm{cm}^{2}\right) \\
& \mathrm{P}=\text { Gaya tekan }(\mathrm{kg})
\end{aligned}
$$

\section{b. Pengujian Kuat Lentur Beton}

Berdasarkan Anonim 5 (1996), kuat lentur beton adalah kemampuan balok beton yang diletakkan pada dua perletakan untuk menahan gaya dengan arah tegak lurus sumbu benda uji yang diberikan padanya sampai benda uji patah. Rumus-rumus perhitungan yang digunakan dalam metode pengujian kuat lentur beton adalah sebagai berikut :

Untuk pengujian dimana patahnya benda uji ada di daerah pusat pada 1/3 jarak titik perletakan pada bagian tarik beton, maka kuat lentur beton dihitung menurut persamaan:

$$
\sigma 1=\frac{P .1}{b \cdot h^{2}}
$$

di mana:

$\sigma 1=$ Kuat lentur benda uji (MPa)

$\mathrm{P}=$ Beban tertinggi yang dilanjutkan oleh mesin uji (Kn)

1 = Jarak (bentang) antara dua garis perletakan ( $\mathrm{mm})$

$\mathrm{b}=$ Lebar tampang lintang patah arah horizontal $(\mathrm{mm})$

$\mathrm{h}=$ Lebar tampang lintang patah arah vertikal $(\mathrm{mm})$

$\mathrm{a}=$ Jarak rata-rata antara tampang lintang patah dan tumpuan luar yang terdekat, diukur pada 4 tempat pada sisi titik dari bentang $(\mathrm{m})$.

\section{Metode Penelitian}

Secara garis besar tahapan penelitian ini meliputi persiapan, pelaksanaan, dan analisis data. Pada tahap persiapan, penelitian ini dimulai dengan studi literatur yang dilanjutkan dengan persiapan dan pengadaan material, yaitu: agregat halus, agregat kasar, semen portland, air dan bahan tambah (serat). Pemeriksaan sifat-sifat fisis dan kandungan bahan organik agregat dilakukan sebelum perencanaan campuran beton (mix design). 
Sedangkan tahap pelaksanaan, dilakukan pembuatan beton, perawatan beton, dan pengujian beton. Untuk pembuatan beton dicampur dengan 3 variasi serat $(5 \%, 10 \%$, dan $15 \%)$ dari berat semen, dicetak dalam cetakan selinder dan balok. Setelah 24 jam cetakan beton dibuka, lalu dilakukan perendaan sampel beton selama 28 hari. Kemudian dilakukan pengujian kuat tekan dan kuat lentur beton, dan dihitung kuat tekan serta kuat lenturnya. Untuk tahap analisis, data yang diperoleh dari hasil pengujian kuat tekan dan kuat lentur selanjutnya dianalisa. Setelah semua data tersebut dianalisa maka dilakukan pembahasan terhadap hasil analisa dan ditarik kesimpulan serta saran.

Sebelum membuat campuran beton, terlebih dahulu mempersiapkan bahanbahan yang akan digunakan dalam proses pembuatan beton untuk diuji sifat-sifat fisis materialnya. Bahan baku tandan kosong kelapa sawit diperoleh dari Kuala Simpang, Aceh Tamiang yang masih basah, dijemur dan sudah dicacah dengan menggunakan mesin, selanjutkan dipisahkan untuk diambil seratnya. Jenis semen yang dipakai adalah semen porland, yaitu Semen Andalas Indonesia strip biru. Sedangkan untuk agregat halus dan agregat kasar digunakan agregat yang diperoleh dari Krueng Mane, Aceh Utara dan air digunakan yang tersedia di Laborotarium Teknik Sipil Universitas Malikussaleh.

\subsection{Pembuatan benda uji}

Langkah pertama dalam pembuatan benda uji adalah persiapan alat. Alatalat yang digunakan untuk pekerjaan ini yaitu: cetakan benda uji, tongkat pemadat dari besi, martil karet, sendok beton, dan peralatan slump test. Jumlah dan jenis benda uji dengan variasi serat dapat dilihat pada Tabel 3:

Tabel 3 Jenis dan jumlah benda uji

\begin{tabular}{|c|c|c|c|}
\hline \multirow{2}{*}{ Benda Uji } & Nama Benda Uji & Variasi Serat (\%) & Jumlah \\
\hline \multirow{4}{*}{ Balok } & B0a, B0b, B0c & 0 & 3 \\
\cline { 2 - 4 } & B5a, B5b, B5c & 5 & 3 \\
\cline { 2 - 4 } & B10c, B10b, B10c & 10 & 3 \\
\cline { 2 - 4 } & B15a, B15b, B15c & 15 & 3 \\
\hline \multirow{3}{*}{ Selinder } & S0a, S0b, S0c & 0 & 3 \\
\cline { 2 - 4 } & S5a, S5b, S5c & 5 & 3 \\
\cline { 2 - 4 } & S10c, S10b, S10c & 10 & 24 \\
\cline { 2 - 4 } & S15a, S15b, S15c & 15 & 3 \\
\hline
\end{tabular}

Jumlah benda uji yang dibuat yaitu sebanyak 24 buah benda uji, terdiri dari 12 benda uji silinder berdiameter $150 \mathrm{~mm}$ dan tinggi $300 \mathrm{~mm}$ dan 12 benda uji balok dengan dimensi $600 \mathrm{~mm}$ x $150 \mathrm{~mm}$ x $150 \mathrm{~mm}$. Mixer yang digunakan adalah mixer listrik kapasitas 0,005 $\mathrm{m} 3$, sehingga pembuatan benda uji dilakukan secara bertahap untuk setiap jenis variasi serat pada setiap jenis benda uji.

Pembuatan benda uji dilakukan sesuai dengan procedural referensi pada Anonim 3 (1993) khususnya pada pembuatan benda uji untuk kondisi pada beton normal, serta mengacu pada Anonim 10 (2012). 


\section{Hasil dan Pembahasan \\ 4.1 Hasil}

\subsubsection{Kuat tekan beton}

Dari hasil pengujian kuat tekan yang dilakukan setalah umur beton mencapai 28 hari, maka didapat kuat tekan beton normal sebesar 24,345 Mpa. Terjadi penurunan kuat tekan yang sangat drastis pada penambahan $10 \%$ serat tandan kelapa sawit, yaitu sebesar 19,439 Mpa. Untuk lebih selengkapnya diperlihatkan pada Tabel 4.

Tabel 4 Hasil pengujian kuat tekan beton

\begin{tabular}{|c|c|c|c|c|c|}
\hline NO & $\begin{array}{c}\text { Serat } \\
(\%)\end{array}$ & $\begin{array}{c}\text { Umur } \\
(\mathbf{h a r i})\end{array}$ & $\begin{array}{c}\text { Slump } \\
(\mathbf{m m})\end{array}$ & $\begin{array}{c}\text { Kuat Rerata } \\
(\mathbf{M p a})\end{array}$ & $\begin{array}{c}\text { Waktu Runtuh } \\
\text { Rerata } \\
(\mathbf{S})\end{array}$ \\
\hline 1 & $0 \%$ & 28 & 78 & $\mathbf{2 4 . 3 4 5}$ & 40.0 \\
\hline 2 & $5 \%$ & 28 & 120 & $\mathbf{2 1 . 1 3 7}$ & 58.0 \\
\hline 3 & $10 \%$ & 28 & 80 & $\mathbf{1 9 . 4 3 9}$ & 76.7 \\
\hline 4 & $15 \%$ & 28 & 90 & $\mathbf{2 0 . 1 9 3}$ & 89.3 \\
\hline
\end{tabular}

Dari Tabel 4 di atas umumnya penambahan serat tandan sawit dapat menurunkan kuat tekan beton, tetapi manfaat lain dari penambahan serat tandan sawit dalam campuran beton dapat meningkatkan waktu runtuh beton.

\subsubsection{Kuat lentur beton}

Dari hasil pengujian kuat lentur yang dilakukan setalah umur beton mencapai 28 hari, maka didapat kuat lentur beton normal sebesar 3,49 Mpa. Terjadi peningkatan kuat lentur yang sangat signifikan pada penambahan $10 \%$ serat tandan kelapa sawit, yaitu sebesar 4,18 Mpa. Untuk lebih lengkapnya diperlihatkan pada Tabel 5:

Tabel 5 Hasil pengujian kuat lentur beton

\begin{tabular}{|c|c|c|c|c|}
\hline NO & $\begin{array}{c}\text { Serat } \\
(\boldsymbol{\%})\end{array}$ & $\begin{array}{c}\text { Umur } \\
(\text { hari })\end{array}$ & $\begin{array}{c}\text { Slump } \\
(\mathbf{m m})\end{array}$ & $\begin{array}{c}\text { Kuat Lentur Rata Rata } \\
(\mathbf{M p a})\end{array}$ \\
\hline 1 & $0 \%$ & 28 & 90 & $\mathbf{3 . 4 9}$ \\
\hline 2 & $5 \%$ & 28 & 130 & $\mathbf{3 . 8 0}$ \\
\hline 3 & $10 \%$ & 28 & 100 & $\mathbf{4 . 1 8}$ \\
\hline 4 & $15 \%$ & 28 & 80 & $\mathbf{3 . 9 1}$ \\
\hline
\end{tabular}

Dari Tabel 5 umumnya penambahan serat tandan sawit dapat meningkatkan kuat lentur beton, dan terjadi penurunan kembali pada variasi $15 \%$ serat tanda sawit.

\subsection{Pembahasan}

\subsubsection{Kuat tekan beton}

Dari Tabel 5 dapat dilihat bahwa penggunaan serat dalam beton dapat berpengaruh terhadap kuat tekan beton, yaitu menurunkan kuat tekan beton. Hal ini dikarenakan penulangan serat dalam beton terjadi secara alami, dan bisa saja penulangannya tidak sesuai dengan arah beban yang diterima dan sehinggag dapat menghalangi pengikatan antar material. Penggunaan serat tanda sawit 5\% dari berat volume semen diperoleh kuat tekan rata-rata sebesar 21,137 Mpa, sehingga 
terjadi penurunan kuat tekan $13,18 \%$. Untuk serat $10 \%$ diperoleh kuat tekan ratarata sebesar 19,439 Mpa dan penurunan kuat tekan 20,15\%, begitu juga dengan penambahan serat $15 \%$ diperoleh kuat tekan rata-rata sebesar 20,193 Mpa dan penurunan kuat tekan sebesar $17,05 \%$. Penurunan kuat tekan pada setiap variasai serat lebih jelasnya diperlihatkan pada Gambar 1:

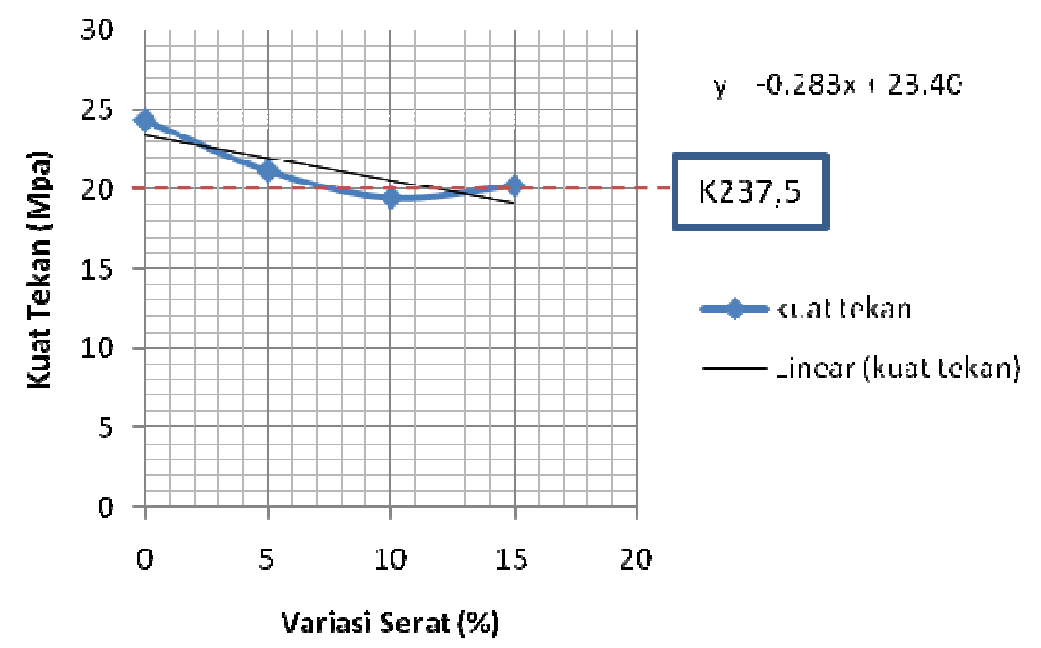

Gambar 1 Grafik kuat tekan beton rata-rata

Namun penggunaan serat tandan sawit sebagai bahan tambah campuran beton masih dapat diterima, hal ini dikarekan kuat tekan yang dihasilkan masih memenuhi persyaratan sebagai beton struktural lebih besar atau sama dengan 17,5 Mpa (Anonim 7, 2002).

\subsection{Kuat lentur beton}

Dari Tabel 5 dapat dilihat bahwa penggunaan serat dalam beton dapat berpengaruh terhadap kuat lentur beton, yaitu meningkatkan kuat lentur beton. Pengaruh penggunaan serat untuk setiap persentase diperliatkan pada Gambar 4.5.

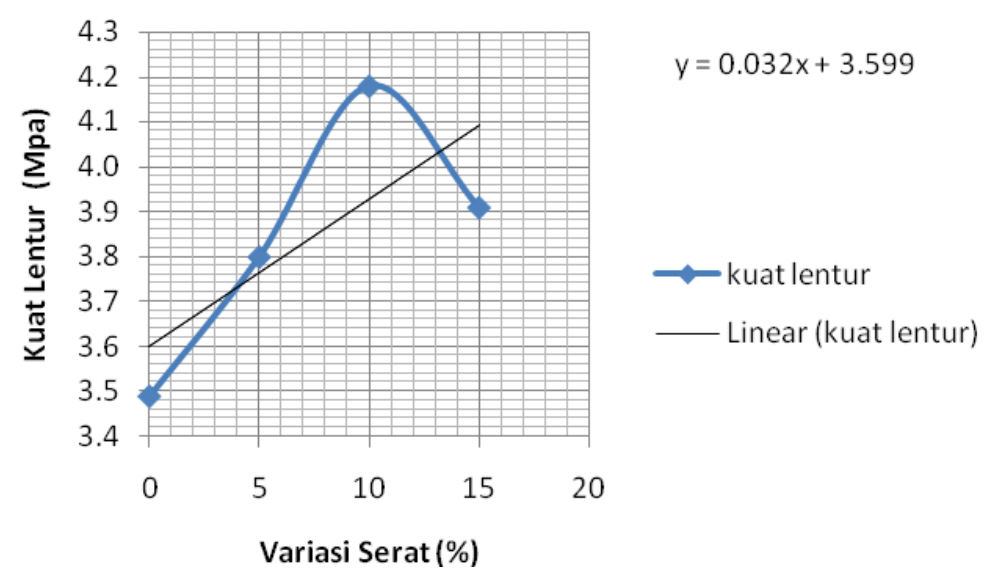

Gambar 2 Grafik kuat lentur beton rata-rata 
Dari Gambar 2 dapat dilihat bahwa pemanfaatan serat tandan sawit terhadap kuat lentur beton memberi manfaat yang baik. Pemanfaatan serat tandan sawit untuk serat beton dapat mengurangi atau memperkecil penggunaan besi pada balok beton, sehingga biaya dapat diminimalkan. Dan ini membuka peluang besar untuk terus mengolah limbah tandan sawit untuk dijadikan serat beton.

\section{Hubungan kuat tekan dan kuat lentur beton}

Dilihat dari kedua persamaan regresi linier yang dihasilkan oleh Gambar 1 dan 2, maka dengan mengunakan metode numerik dapat diketahui kumposisi optimum yang dapat meningkatkan kuat lentur beton dengan kuat tekan beton masih dalam batasan kuat tekan rencana. Variasi serat yang dimaksud yaitu pada variasi $12 \%$ serat dengan kuat lentur 3,99 Mpa dan kuat tekan 20 Mpa seperti yang diperlihatkan pada Gambar 4.6:

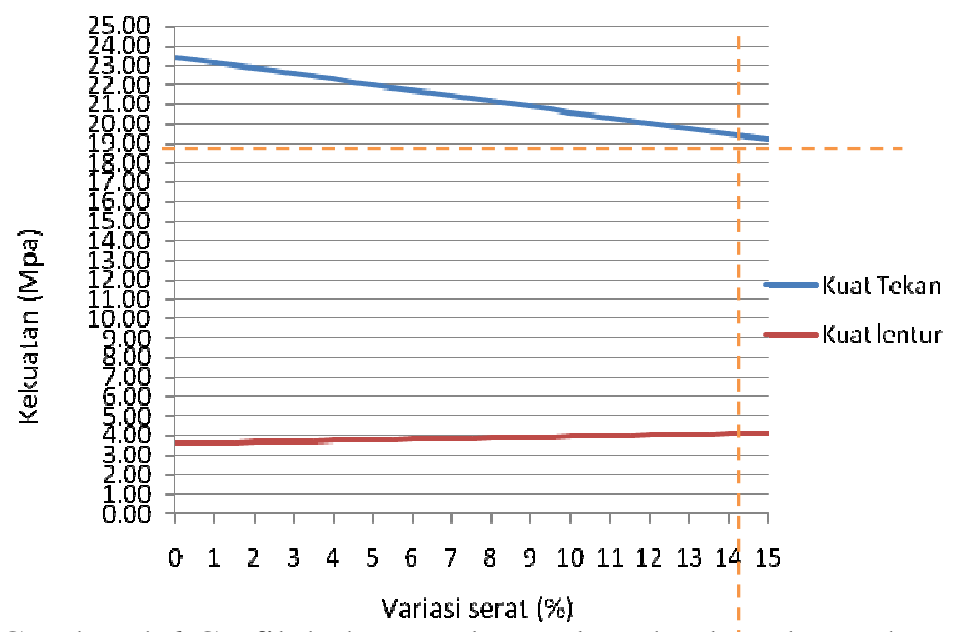

Gambar 4.6 Grafik hubungan kuat tekan dan kuat lentur beton

\section{$5 \quad$ Kesimpulan dan Saran}

\subsection{Kesimpulan}

Dari hasil penelitian yang telah dilakukan dapat diambil beberapa kesimpulan sebagai berikut:

1. Pengaruh penambahan serat tanda sawit dalam campuran pada setiap veriasi persentase serat $(5 \%, 10 \%, 15 \%)$ tidak dapat meningkatkan kuat tekan beton. Sedangkan untuk kuat lentur peningkatan maksimum pada penambahan serat tandan sawit sebanyak 10\%, yaitu sebesar $19.77 \%$ dari kuat lentur normal. Berdasarkan persamaan regresi linier, komposisi optimum yang dapat meningkatkan kuat lentur beton dengan kuat tekan beton masih dalam batasan kuat tekan rencana, yaitu pada variasi $12 \%$ serat dengan kuat lentur $3.99 \mathrm{Mpa}$ (meningkat $14.33 \%$ dari kuat normal) dengan kuat tekan $20 \mathrm{Mpa}$.

2. Penggunaan serat tanda sawit 5\% diperoleh kuat tekan rata-rata sebesar 21,137 Mpa, sehingga penurunan kuat tekan $13,18 \%$, untuk serat $10 \%$ diperoleh kuat tekan rata-rata sebesar 19,439 Mpa dan penurunan kuat tekan 20,15\%, begitu juga penambahan serat $15 \%$ diperoleh kuat tekan rata-rata sebesar 20,193 Mpa dan penurunan kuat tekan sebesar $17,05 \%$. Sedangkan untuk kuat lentur penggunaan serat tanda sawit 5\% diperoleh kuat lentur rata-rata sebesar 3,8 Mpa, sehingga peningkatan kuat lentur 8,88\%. Untuk serat $10 \%$ diperoleh kuat 
lentur rata-rata sebesar 4.18 Mpa dan peningkatan kuat lentur $19,77 \%$, begitu juga untuk serat $15 \%$ diperoleh kuat lentur rata-rata sebesar 3,91 Mpa dan peningkatan kuat lentur sebesar $12,03 \%$.

3. Penambahan serat tanda sawit dalam campuran dapat memperlambat waktu runtuhnya beton, dan peningkatan terbesar terjadi pada penambahan $15 \%$ serat dari berat volume semen, yaitu sebesar $123.25 \%$ dari waktu normal.

\subsection{Saran}

Berdasarkan permasalahan yang terjadi dan kesimpulan-kesimpulan di atas dapat disarankan sebagai bentuk rekomendasi sebagai berikut:

1. Untuk beton non struktural dapat digunakan tandan kelapa sawit agar kuat tekan beton dapat ditingkatkan

2. Perlu adanya penelitian lanjutan terhadap campuran yang lebih variatif untuk memperkuat hasil penelitian ini.

\section{Daftar Kepustakaan}

Anonim 1, 2000, SNI 03-2834-2000: Mix Design, BSNI, Jakarta

Anonim 2, 2008, SNI 1970:2008: Cara uji berat jenis dan penyerapan air agregat halus, BSNI, Jakarka.

Anonim 3, 1993, SNI 03-2834-1993: Tata Cara Pembuatan Rencana Campuran beton Normal, BSNI, Jakarta.

Anonim 4, 2004, SNI 15-2049-2004: Semen Portland, BSNI, Jakarta.

Anonim 5, 1996, SNI 03-4431-1997: Metode Pengujian Kuat Lentur Normal dengan dua titik pembebanan, BSNI, Jakarta.

Anonim 6, 1990, SNI 03-1974-1990: Metode pengujian kuat tekan beton, BSNI, Jakarta.

Anonim 7, 2002, SNI 03-2847-2002: Tata Cara Perhitungan Struktur Beton Untuk Bangunan Gedung, BSNI, Jakarta.

Anonim 8, 2002, ASTM: Standard Specification for Concrete Agregates, Department Of Defense, United States.

Anonim 9, 2007, SNI DT - 91- 0008 - 2007: Tata Cara Perhitungan Harga Satuan Pekerjaan Beton, Dept Pekerjaan Umum, Jakarta.

Anonim 10, 2012, Modul Praktikum Teknologi Bahan Konstruksi Laboratorium Teknik Sipil Universitas Malikussaleh, Lhokeseumawe.

Anonim 11, 2003, ASTM: Standar Test Method for Dessity of Hydraulic Cement, Department Of Defense, United States.

Gurning, Nuria, 2013, Pembuatan Beton Serat Tandan Kosong Kelapa Sawit, Telaah Jurnal Ilmu Pengetahuan dan Teknologi, Tangerang.

Mulyono,T., 2004, Teknologi Beton, Penerbit Andi, Yogyakarta.

Subyakto, 2012, Serat Alam Sebagai Bahan Baku Industri Biokomposit, www.xa.yimg.com, diunduh tanggal 04 September 2013.

Wang, Chu-Kia., G. salmon, Charles, 1993, Desain Beton Bertulang, Binsar Hariandja, Erlangga, Jakarta. 